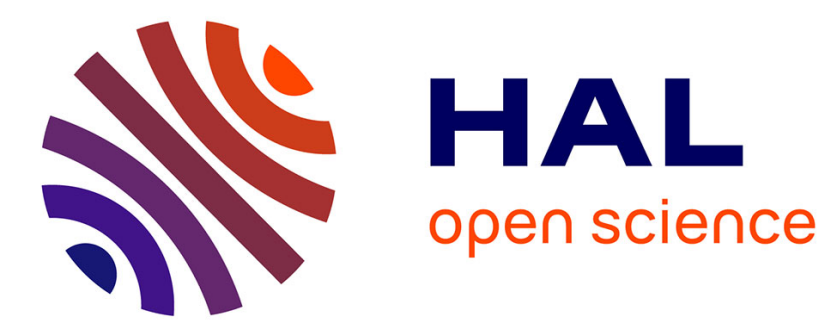

\title{
Label-free detection of anticancer drug paclitaxel in living cells by confocal Raman microscopy
}

Hamideh Salehi, L. Derely, Attila Gergely Vegh, J.-C. Durand, Csilla Gergely, Christian Larroque, M.-A. Fauroux, Frédéric J. G. Cuisinier

\section{- To cite this version:}

Hamideh Salehi, L. Derely, Attila Gergely Vegh, J.-C. Durand, Csilla Gergely, et al.. Label-free detection of anticancer drug paclitaxel in living cells by confocal Raman microscopy. Applied Physics Letters, 2013, 102 (11), pp.113701. 10.1063/1.4794871 . hal-00803173

\section{HAL Id: hal-00803173 https://hal.science/hal-00803173}

Submitted on 25 May 2021

HAL is a multi-disciplinary open access archive for the deposit and dissemination of scientific research documents, whether they are published or not. The documents may come from teaching and research institutions in France or abroad, or from public or private research centers.
L'archive ouverte pluridisciplinaire HAL, est destinée au dépôt et à la diffusion de documents scientifiques de niveau recherche, publiés ou non, émanant des établissements d'enseignement et de recherche français ou étrangers, des laboratoires publics ou privés. 


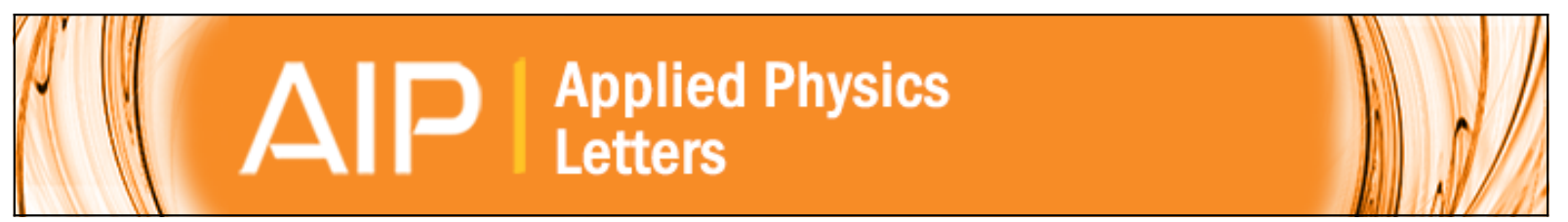

Label-free detection of anticancer drug paclitaxel in living cells by confocal Raman microscopy

H. Salehi, L. Derely, A.-G. Vegh, J.-C. Durand, C. Gergely, C. Larroque, M.-A. Fauroux, and F. J. G. Cuisinier

Citation: Applied Physics Letters 102, 113701 (2013); doi: 10.1063/1.4794871

View online: http://dx.doi.org/10.1063/1.4794871

View Table of Contents: http://scitation.aip.org/content/aip/journal/apl/102/11 ?ver=pdfcov

Published by the AIP Publishing 


\title{
Label-free detection of anticancer drug paclitaxel in living cells by confocal Raman microscopy
}

\author{
H. Salehi, ${ }^{1}$ L. Derely, ${ }^{1}$ A.-G. Vegh, ${ }^{1,2}$ J.-C. Durand, ${ }^{1}$ C. Gergely, ${ }^{3,4}$ C. Larroque,${ }^{5}$ \\ M.-A. Fauroux, ${ }^{1}$ and F. J. G. Cuisinier ${ }^{1}$ \\ ${ }^{1}$ Laboratoire Biologie-Santé Nanosciences, EA 4203, UFR Odontologie, Université Montpellier 1, \\ Montpellier 34193, France \\ ${ }^{2}$ Institute of Biophysics, Biological Research Centre of the Hungarian Academy of Sciences, \\ 6726 Szeged, Hungary \\ ${ }^{3}$ Université Montpellier 2, Laboratoire Charles Coulomb UMR 5221, F-34095 Montpellier, France \\ ${ }^{4}$ CNRS, Laboratoire Charles Coulomb UMR 5221, F-34095 Montpellier, France \\ ${ }^{5}$ IRCMIINSERM896, Centre Régional de Lutte contre le Cancer Val d'Aurelle - Paul Lamarque, \\ Université Montpellier 1, 34298 Montpellier, France
}

(Received 18 June 2012; accepted 18 December 2012; published online 18 March 2013)

\begin{abstract}
Confocal Raman microscopy, a non-invasive, label-free, and high spatial resolution imaging technique is employed to trace the anticancer drug paclitaxel in living Michigan Cancer Foundation7 (MCF-7) cells. The Raman images were treated by K-mean cluster analysis to detect the drug in cells. Distribution of paclitaxel in cells is verified by calculating the correlation coefficient between the reference spectrum of the drug and the whole Raman image spectra. A time dependent gradual diffusion of paclitaxel all over the cell is observed suggesting a complementary picture of the pharmaceutical action of this drug based on rapid binding of free tubulin to crystallized paclitaxel. (C) 2013 American Institute of Physics. [http://dx.doi.org/10.1063/1.4794871]
\end{abstract}

Paclitaxel has been used extensively as an antitumor, ${ }^{1}$ anti-leukemic drug, ${ }^{2}$ and recently its benefiting effect in preventing restenosis has been reported. ${ }^{3}$ Paclitaxel is also used in cell biology research, as a pro-apoptotic drug. In a classical view paclitaxel $\left(\mathrm{C}_{47} \mathrm{H}_{51} \mathrm{NO}_{14}\right.$, molecular weight $\left.835 \mathrm{Da}\right)$ is categorized as a microtubule-stabilizing agent. ${ }^{4}$ It binds directly to the inner surface of microtubules, inducing a conformational change that increases its affinity for neighbor tubulin. Paclitaxel strongly reduces the free energy of polymerization, increases sharply microtubules mass, and their dynamic elongation is almost completely suppressed. ${ }^{5,6} \mathrm{~A}$ recent study showed that the paclitaxel molecule binds also to a second site, forming a groove between $\alpha$-tubulin and $\beta$ tubulin monomers. ${ }^{7}$ In this case the molecule is partially exposed to the solution and may serve as a bridge, connecting other paclitaxel molecules and leading to the formation of paclitaxel spherulites that are frequently mistaken for microtubule asters. ${ }^{7}$ Moreover, at commonly used concentrations $(1-20 \mu \mathrm{M})$ paclitaxel binds tubulin subunits rather than microtubule generating asters and bundles that can masquerade as stabilized microtubules. ${ }^{8}$ This unexpected property of the drug would lead to reinterpretation of many microtubulebased studies. It is then worthwhile to carefully investigate internalization of paclitaxel in living cells in order to study the validity of this theory. The observation of paclitaxel forming asters of high diameters ${ }^{7}$ would confirm it, and also spreading of paclitaxel all over the cell will challenge the classical theory.

Common methods to study distribution and mapping of drugs in fixed and live cells include use of fluorescent labeling. ${ }^{9}$ Although fluorescence techniques are well established, certain difficulties are encountered, such as low contrast and photo-bleaching; also, introduction of fluorescent labels may potentially alter the biochemical properties of the molecule of interest. Alternatively confocal Raman microscopy appears as a unique tool for chemical cell imaging and protein conformation imaging. ${ }^{10-14}$ Raman spectra of cells are very complex because they contain the fingerprints of all molecules present. Raman spectral maps of individual cells ${ }^{15-18}$ and localization of intracellular nanoparticles ${ }^{12,19,20}$ have been achieved. The main advantages of confocal Raman microscopy include high spatial resolution and a unique compositional sensitivity intrinsic to spectroscopic methods. ${ }^{9}$ Tracing drugs within cells no longer need any label since the drug's Raman signature enables their detection in the cell. Moreover, cell's Raman spectra can be also recorded reflecting the cell's biochemical composition in the laser spot volume. Since the spectral contrast between cellular components is relatively small, images need to be treated using multivariate methods of analysis. ${ }^{21}$ By direct Raman microscopy, Raman images of MDA-435 breast cancer cells treated with highly concentrated $(350 \mu \mathrm{M})$ paclitaxel have been acquired at a single selected Raman peak $\left(1000 \mathrm{~cm}^{-1}\right)$ with $0.54 \mu \mathrm{m}$ resolution. ${ }^{22}$ In this work we provide data on paclitaxel distribution at close to clinical concentrations $(\approx 10 \mu \mathrm{M})$ in live cancerous MCF-7 (Michigan Cancer Foundation-7) cells based on a set of Raman spectral lines of paclitaxel, using a higher resolution $(300 \times 300$ $\times 800 \mathrm{~nm}$ ) confocal Raman spectroscopy. For better image contrast we complete the experimental work with cluster analysis and correlation map calculations.

The MCF-7 cells, derived from a metastatic breast cancer patient in 1970, were the first cancer cell line capable of living longer than few months and now became a standard model in cancer research laboratories. ${ }^{23} \mathrm{MCF}-7$ were grown in $75 \mathrm{~cm}^{2}$ culture flasks (VWR, Strasbourg, France) in a media containing $7 \mathrm{ml}$ DMEM (Dulbecco's modified eagle's medium), (Thermo Fisher, Strasbourg, France), 20\% FBS, and 1\% antibiotics (Streptomycin $100 \mu \mathrm{g} / \mathrm{ml}$ penicillin, $100 \mathrm{U} / \mathrm{ml}$ ) at 
$37^{\circ} \mathrm{C}$ and $5 \% \mathrm{CO}_{2}$. Cells were cultivated onto polished $\mathrm{CaF}_{2}$ substrates (Crystran Ltd, Dorset, UK). $\mathrm{CaF}_{2}$ reveals a Raman peak at $320 \mathrm{~cm}^{-1}$ and hence has no interference with major cell's Raman lines. After $24 \mathrm{~h}$ the cells adhered on $\mathrm{CaF}_{2}$ substrate. Paclitaxel (Taxol, Teva Pharmaceutical Ind., Tel Aviv, Israel) was then added to the culture medium: cells were incubated for three, six, and nine hours in DMEM containing paclitaxel and then washed three times with PBS (Phosphate Buffer Saline) (Invitrogen, Grand Island, USA), enabling the time tracing of paclitaxel in the cell. The $\mathrm{CaF}_{2}$ substrates with adhered cells were transferred into Petri dishes containing $5 \mathrm{ml}$ PBS. PBS was selected because it does not create fluorescence as DMEM. Clinical amount of paclitaxel in each treatment injection, given by pharmaceutical manufacturer, is $175 \mathrm{mg} / \mathrm{m}^{2}$. By using Mosteller formula for body surface area and then Hume-Weyer formula for total body water, we are able to calculate the equivalent amount of paclitaxel for cell culture medium that in our experiments is $9.7 \mu \mathrm{g} / \mathrm{ml}$. Tracking of time-dependent distribution of paclitaxel in cells was followed by Raman microscopy. Raman spectra were collected using a Witec confocal Raman microscope system alpha 300R (Witec Inc., ULM, Germany). Excitation in the confocal Raman microscopy is assured by a frequency doubled Nd:YAG laser (Newport, Evry, France) at a wavelength of $532 \mathrm{~nm}, 50 \mathrm{~mW}$ power at laser output, single longitudinal mode. The light is carried to microscope by a multimode fiber (diameter of $125 \mu \mathrm{m}$ ). The incident laser beam is focused onto the sample through a $\times 60$ NIKON water immersion objective having a numerical aperture of 1.0 , and a working distance of $2.8 \mathrm{~mm}$ (Tokyo, Japan). The acquisition time of a single spectrum was $0.5 \mathrm{~s}$. 150 points per line and 150 lines per image were recorded, leading to a total of 22500 spectra for one image, each spectrum corresponding to a spatial unit defined as a voxel. We present in Fig. 1(a) the bright field image of MCF7 living cells in PBS solution. The low contrast in the bright field image is due to the absence of staining. (c) Refers to the total integrated Raman intensities of the $\mathrm{CH}$-stretching mode, in specific spectrum regions

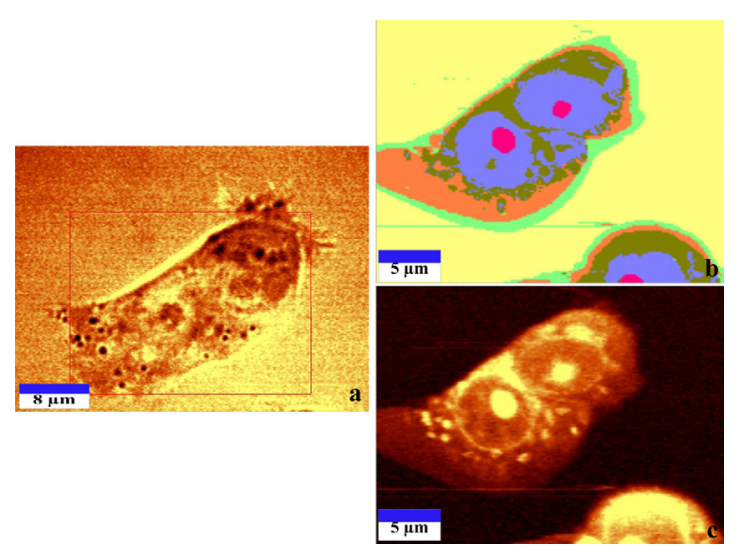

FIG. 1. (a) Bright-field microscopic image of MCF-7 cell in buffer solution, $60 \times$ objective. (b) Integrated Raman intensities in the $2800-3000 \mathrm{~cm}^{-1}$ region of the cell shown in (a) collected at a dwell time of $0.5 \mathrm{~s} /$ point and a point spacing of around $300 \mathrm{~nm}$. Bright yellow hues indicate the highest and dark hues the lowest integrated $\mathrm{C}-\mathrm{H}$ stretching intensities, respectively. (c) Raman image of various cell components obtained via KMCA clusters based on data shown in (b) and corresponding to the Raman spectra region of $500-1800 \mathrm{~cm}^{-1}$ and $2600-3200 \mathrm{~cm}^{-1}$.
(2800-3000 $\mathrm{cm}^{-1}$ ) corresponding to the $\mathrm{CH}$ band. The Witec Project software provides a Sum Filter. By choosing the specific spectra region in Sum Filter, we could extract an image based on integrated Raman intensities of a specific region. Bright yellow hues indicate highest intensities and dark hues the lowest integrated intensities of the chosen region, respectively. In (c), bright yellow hues corresponding to high intensities of $\mathrm{CH}$ stretching band, belong inside the cell and dark hues the lowest integrated intensities of $\mathrm{CH}$ stretching band belong to PBS with no $\mathrm{CH}$ band. (b) Shows the results of K-mean cluster analysis (KMCA) of the data set for six clusters. K-means clustering partitions data into $\mathrm{k}$ mutually exclusive clusters. K-means treats each observation in the data set as an object having a location in space. It finds a partition in which objects within each cluster are as close to each other as possible, and as far from objects in other clusters as possible. $\mathrm{K}$-means uses an iterative algorithm that minimizes the sum of distances from each object to its cluster centroid, over all clusters. This algorithm moves objects between clusters until the sum cannot be decreased further. The result is a set of clusters that are as compact and well-separated as possible

$$
\sum S_{i}^{J}-m_{k}
$$

The distance between each spectral vectors $S_{i}^{J}$ and cluster centroids $m_{k}$ has to be minimized for each group of clusters. ${ }^{21}$ KMCA was realized using the Witec Project Plus (Ulm, Germany) software. K-mean clustering was performed in the $500-1800 \mathrm{~cm}^{-1}$ and $2600-3200 \mathrm{~cm}^{-1}$ spectral domains. These regions were chosen because they contain sufficient spectral information of cell components and provide the best clustering results. Figure 1(c) depicts a Raman image constructed via KMCA revealing clusters matching nucleus (blue), nucleolus (pink), cytoplasm (orange), membrane (light green), endoplasmic reticulum (dark green), as well as different components in cytoplasm.

In Fig. 2 we present a typical Raman spectrum of a cell (a), the Raman spectrum of the paclitaxel solution prepared from paclitaxel (Teva Ind, Tel Aviv, Israel) (b) and the Raman spectrum of paclitaxel (Sigma-Aldrich, France 95\%

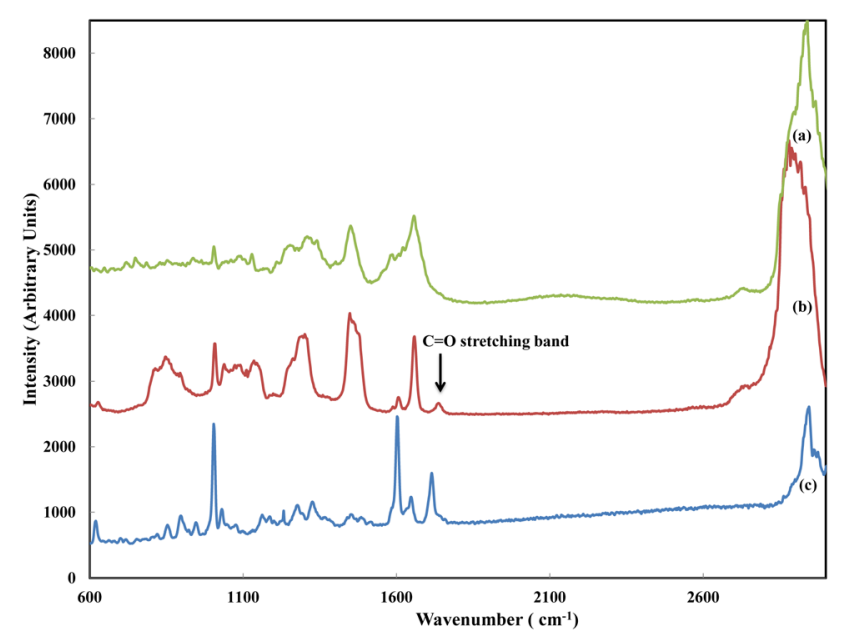

FIG. 2. Predominant bands in the Raman spectra of (a) cytoplasm and endoplasmic reticulum; (b) clinical paclitaxel solution from Teva Ind.; (c) pure paclitaxel powder from Sigma-Aldrich. 

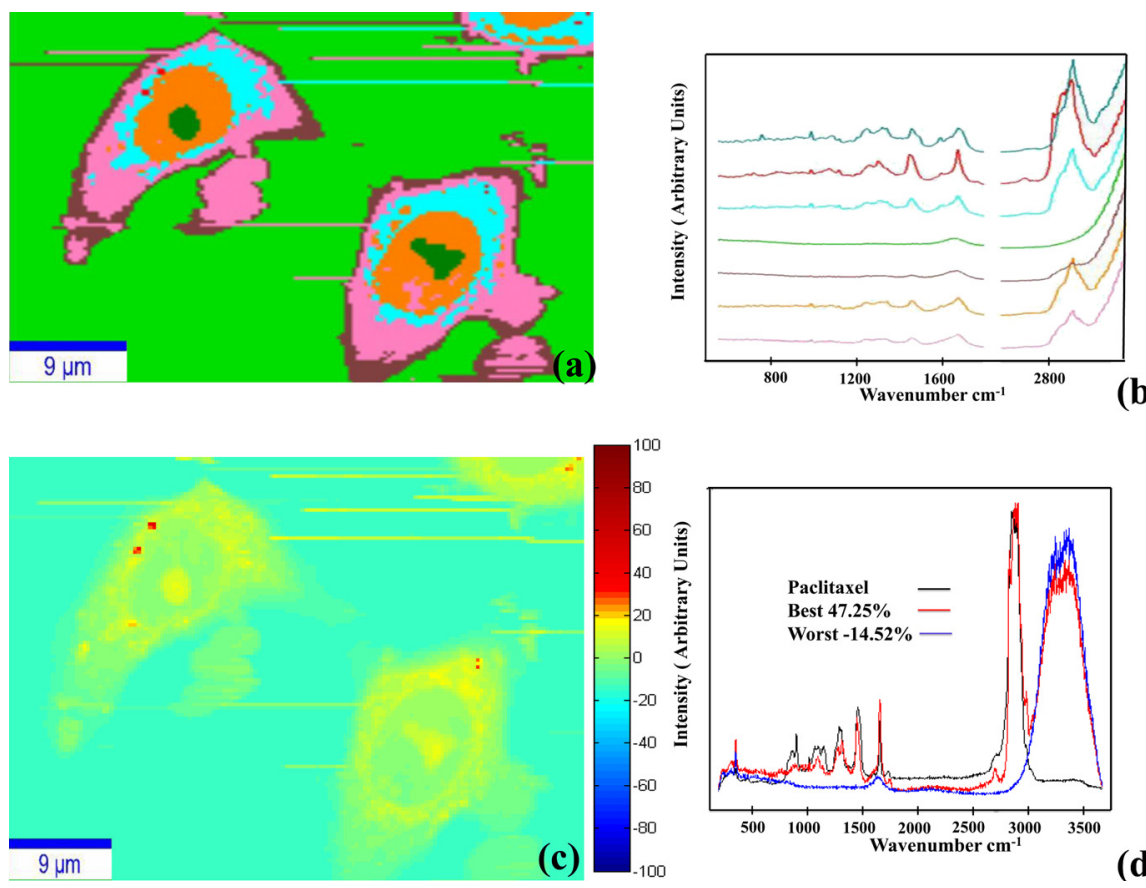

FIG. 3. (a) Seven cluster Raman map of MCF7 cells. (b) Average spectra corresponding to clusters in (a) (same colors as in (a)): the average spectra of nucleus (orange) nucleolus (dark green), cytoplasm (pink), membrane (brown), endoplasmic reticulum (light blue), PBS buffer (light green) and paclitaxel (red). (c) Correlation map of the same image. (d) The correlation coefficient between the whole spectra and the one of paclitaxel taken as a reference (black spectrum). The best correlation is obtained for the paclitaxel in cell (red spectrum); the region with no correlation to paclitaxel is due to the PBS buffer (blue spectrum). purity) in powder (c), respectively. The Raman vibrations obtained for the paclitaxel used in our research are very similar to the spectra previously reported for functional derivatives of the paclitaxel. ${ }^{6}$ Comparison between Figs. 2(a) and 2(b) shows that most of Raman peaks appearing in the spectra of cells overlap with the vibrational peaks of the paclitaxel. Moreover, the previously used peak by Ling et $a .^{22}$ at $1002 \mathrm{~cm}^{-1}$ which is due to $\mathrm{sp}^{3}$ hybridized carbon-carbon (C-C) vibration in the paclitaxel occurs also in the cell's spectra. Therefore in our work the peak at $1740 \mathrm{~cm}^{-1}$ (the $\mathrm{C}=\mathrm{O}$ stretching band marked in the red spectrum of Fig. 2(b)) was used to monitor paclitaxel in cells.

Cells cultured for $24 \mathrm{~h}$ in DMEM and then incubated for $3 \mathrm{~h}$ in a solution of DMEM containing paclitaxel $(9.7 \mu \mathrm{M})$ were rinsed with PBS and transferred under the confocal Raman microscope. Fig. 3(a) shows the results of KMCA analysis of MCF-7 cell's images, when the cells were incubated with paclitaxel for three hours. The images reveal seven clusters, corresponding to different parts of the cell and the background signal of the PBS buffer and the $\mathrm{CaF} 2$ substrate. The spectral contrast between cellular components is relatively small as they are very similar in terms of Raman vibrations. But precisely it is possible to reveal very small differences between the various parts of the cell. ${ }^{15,21}$ The average spectra of nucleus (orange) nucleolus (dark green), cytoplasm (pink), membrane (brown), endoplasmic reticulum (light blue), and paclitaxel (red) calculated by KMCA are plotted in Fig. 3(b). The peak positions, band shapes, and intensities are very alike, considering that cell basic components are quite similar; however, there are noticeable differences in specific spectral regions. For example the symmetric uracil or thymine ring breathing mode with a frequency at $785 \mathrm{~cm}^{-1}$ is observed quite strongly for the nuclear and cytoplasmic regions but much less for the mitochondria. ${ }^{9}$ The number of spectra contributing to the average spectra of each cluster is in order of thousands. Consequently the observed signal to noise ratio for an average spectrum is very good. Fig. 3(b) evidences that the (red) spectrum of paclitaxel is very similar to the cell components' spectra; therefore, the drug was monitored after clustering an average spectra containing the specific peak of paclitaxel at $1740 \mathrm{~cm}^{-1}$ ( $\mathrm{C}=\mathrm{O}$ stretching in Fig. 2). As this band has a very low intensity compared to the whole spectra, clustering has to be performed several times. Finally by comparing the cluster of average spectrum with the drug reference spectrum, we are able to identify the cluster corresponding to paclitaxel.

As the paclitaxel (red cluster in Fig. 3(a)) cluster contains several single spectra, each of them was compared to the reference paclitaxel spectrum (Fig. 2) and showed a very good match. Beside the K-mean cluster, a spectral correlation matrix was calculated, ${ }^{21}$ to find the most similar spectrum to the reference spectrum of paclitaxel. To quantify the similarity, as a "distance," the Pearson's correlation
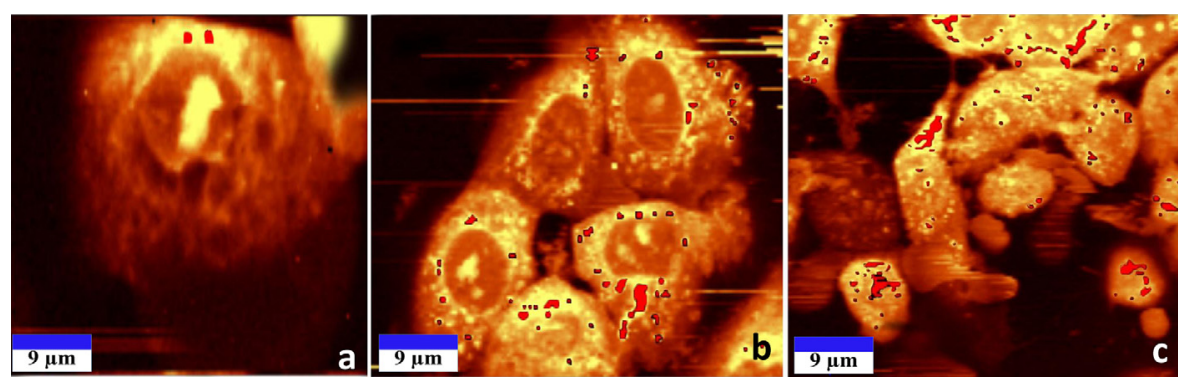

FIG. 4. Raman images of MCF7 cells incubated in paclitaxel. Integrated Raman intensities in the $2800-3000 \mathrm{~cm}^{-1}$ region of the cell, marking paclitaxel as red spot. (a) $3 \mathrm{~h}$; (b) $6 \mathrm{~h}$; (c) $9 \mathrm{~h}$ incubation of cells in culture medium containing paclitaxel. 


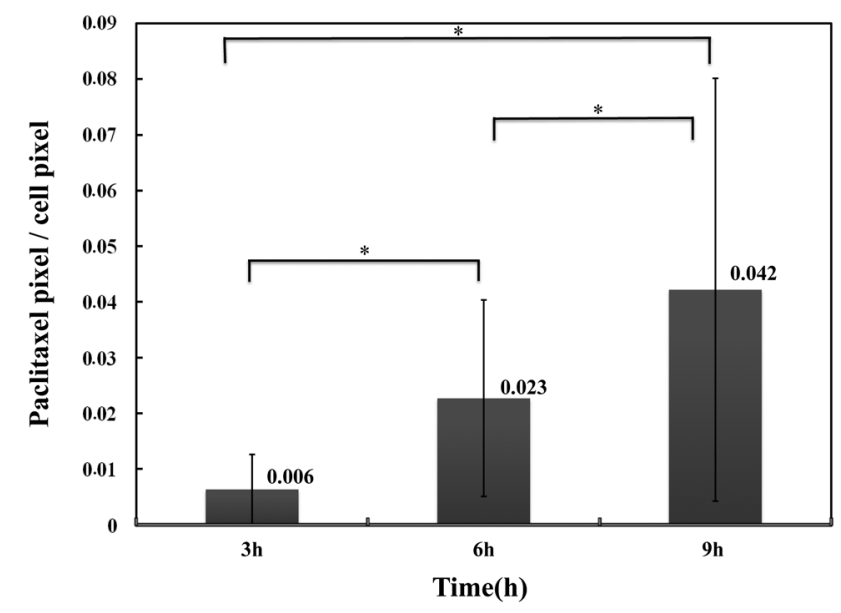

FIG. 5. Paclitaxel pixel over cell pixel at different incubation times in paclitaxel. (*) Student $t$ test approves significance of data.

coefficient was calculated for each pair of spectra, given by the following formula:

$$
\mathrm{r}=\frac{\sum_{i=1}^{N}\left(\left(x_{i}-X\right)\left(y_{i}-Y\right)\right)}{\sqrt{\sum_{i=1}^{N}\left(x_{i}-X\right)^{2} \sum_{i=1}^{N}\left(y_{i}-Y\right)^{2}}}
$$

where $\mathrm{N}$ is the number of points within the spectrum, $\mathrm{x}_{\mathrm{i}}$ and $\mathrm{y}_{\mathrm{i}}$ are the individual points, and $\mathrm{X}$ and $\mathrm{Y}$ are the mean value of each spectrum. The value of $\mathrm{r}$ can vary between -1 and 1 ; thus, it can be expressed as a percentage ranging from $-100 \%$, no correlation, to $100 \%$, the perfect match. From these values, a pseudo color map can be constructed, reflecting the quantified similarities. All calculations were performed with a homemade code written in MatLab (Math Works, Inc, Massachusetts, USA). The correlation coefficient map of the same image is depicted in Fig. 3(c). Paclitaxel spectrum as a reference was compared to all spectra of the same image, resulting in a correlation map shown in Fig. 3(c). The numbers of 100 and -100 in the color bar stand for the best and worst correlation (expressed in \%) between all cell spectra and paclitaxel spectrum. We observe that the lowest correlation $(-14.5 \%$, turquoise color) corresponds to PBS and the best correlation indicated by the red color corresponds to paclitaxel. In the correlation coefficient map the same position of paclitaxel as in the cluster analysis was obtained, confirming our KMCA results. In Fig. 3(d) we present the (black) spectrum of paclitaxel and the corresponding, best correlation (47.2\%, red spectrum) as well as the worst correlation $(-14.5 \%$, blue spectrum) obtained for the phosphate buffer region, respectively. Our analyses demonstrate clearly the capability of KMCA to distinguish paclitaxel based on the molecule's Raman vibrations. Relying on the results of KMCA the next step was tracing paclitaxel versus different incubation times to monitor uptake pathways of the drug in cells. Figure 4 presents the Raman images of MCF-7 cells after different incubation times in paclitaxel
TABLE I. Paclitaxel uptake after 3, 6, and $9 \mathrm{~h}$ of incubation.

\begin{tabular}{cc}
\hline \hline Time $^{\mathrm{a}}(\mathrm{h})$ & $\%$ cells \\
\hline 3 & 85 \\
6 & 80 \\
9 & 90 \\
\hline
\end{tabular}

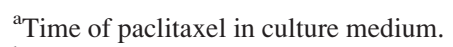

${ }^{\mathrm{b}}$ Percentage of cells positive for paclitaxel/total number of live cells.

solution. The paclitaxel cluster (red) obtained by KMCA was superposed on the Raman image of the cell (integrated Raman intensities in the $2800-3000 \mathrm{~cm}^{-1}$ region, using sum filter) using Image J software (National Institutes of Health, Maryland, USA). Fig. 4(a) shows cells after three hours of incubation in paclitaxel: the drug had passed the cell membrane and entered the cytoplasm.

The same protocol was used to obtain Figs. 4(b) and 4(c), presenting MCF7 cells incubated six and nine hours in paclitaxel containing culture medium, respectively. Images clearly reveal an increase of paclitaxel uptake by cells versus time and its distribution in numerous parts of the cells. The drug is gradually diffusing into the cytoplasm, but it does not enter cell nucleus. The ratio of the number of pixels belonging to paclitaxel cluster over the number of pixels corresponding to the cell was calculated and represented by bars in Fig. 5. This ratio representing the amount of paclitaxel in the cells increases with the incubation time of cells with the drug. The number of cells containing paclitaxel is also increasing with time (Table I). After three hours of culture with paclitaxel $85 \%$ of cells show an uptake of the drug, while after nine hours $90 \%$ were involved. Para-nitrophenyl phosphate (pNPP) and Trypan Blue viability tests show that after incubation for three and six hours in paclitaxel, $80 \%$ of cells were alive and at nine hours incubation, $60 \%$ survived. In other words interpretation of Raman images has to be done considering that for three and six hours of culture with paclitaxel, $80 \%$ of cells were alive, thus still on the $\mathrm{CaF}_{2}$ substrate among these $85 \%$ and $80 \%$ uptake paclitaxel, respectively. After nine hours of culture with paclitaxel only $60 \%$ of cells were still adhered on the $\mathrm{CaF}_{2}$ substrate and among them $90 \%$ uptake paclitaxel.

Intracellular pharmacokinetics of Paclitaxel was developed taking into account saturable drug binding to extracellular proteins, saturable and nonsaturable drug binding to intracellular components, time- and concentration-dependent drug depletion from culture medium, and cell densitydependent drug accumulation. ${ }^{24}$ Differential equations were solved to calculate the paclitaxel concentration in MCF7 cells (Python Software Foundation, Netherland). Initial cell number, initial drug concentration, average cell volume, and medium volume taken from our measurement, Michaelis-Menten constants, and some physical constants for calculation from Kuh et $a .^{24}$ were introduced in differential equations to obtain the time dependent concentration simulation of our measurement.

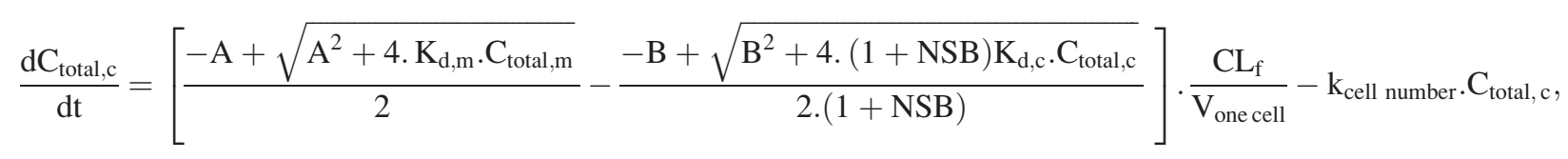




$$
\frac{\mathrm{dC}_{\mathrm{total}, \mathrm{m}}}{\mathrm{dt}}=\left[\frac{-\mathrm{A}+\sqrt{\mathrm{A}^{2}+4 \cdot \mathrm{K}_{\mathrm{d}, \mathrm{m}} \cdot \mathrm{C}_{\mathrm{total}, \mathrm{m}}}}{2}-\frac{-\mathrm{B}+\sqrt{\mathrm{B}^{2}+4 \cdot(1+\mathrm{NSB}) \mathrm{K}_{\mathrm{d}, \mathrm{c}} \cdot \mathrm{C}_{\mathrm{total}, \mathrm{c}}}}{2 \cdot(1+\mathrm{NSB})}\right] \cdot \frac{\mathrm{CL}_{\mathrm{f}} \cdot \mathrm{ICN}_{\mathrm{C}} \mathrm{e}_{\mathrm{k} \text { cell number. }}}{\mathrm{V}_{\mathrm{m}}}
$$

$\mathrm{A}=\mathrm{K}_{\mathrm{d}, \mathrm{m}}+\mathrm{B}_{\mathrm{max}, \mathrm{m}}-\mathrm{C}_{\text {total, } \mathrm{m}}$,

$\mathrm{B}=(1+\mathrm{NSB}) \cdot \mathrm{K}_{\mathrm{d}, \mathrm{c}}+\mathrm{B}_{\max , \mathrm{c}} \cdot\left(1+\mathrm{k}_{\mathrm{Bmax}, \mathrm{c}} \cdot \mathrm{t}\right)-\mathrm{C}_{\mathrm{total}, \mathrm{c}}$,

$\mathrm{V}_{\text {one cell }}=\frac{4 \pi}{3} . \mathrm{L} . \mathrm{W} \cdot \mathrm{H}=2.1 \mu \mathrm{l} / 10^{6}$ cell, average cell volume, $L$ maximum, $W$ minimum diameter of cell, $\mathrm{H}$ height of cell, $V_{m}(5 \mathrm{ml})$ : volume of the medium,

$\mathrm{B}_{\max , \mathrm{m}}(3.94 \mu \mathrm{M}), \mathrm{K}_{\mathrm{d}, \mathrm{m}}(781 \mathrm{nM})$ : Michaelis-Menten constants of drug binding to cellular components,

$\mathrm{B}_{\max , \mathrm{c}}(59.2 \mu \mathrm{M}), \mathrm{K}_{\mathrm{d}, \mathrm{c}}(4.93 \mathrm{nM})$ : Michaelis-Menten constants of drug binding to protein in medium,

NSB (0.148): Proportionality constant for nonsaturable binding site in cells

$\operatorname{ICN}\left(10^{6}\right)$ : initial cell number,

$\mathrm{CL}_{\mathrm{f}}\left(3.34 \times 10^{-3} \mu \mathrm{l} / \mathrm{h} /\right.$ cell $)$ : Clearance of free drug by passive diffusion,

$\mathrm{k}_{\text {cell number }}\left(-0.0053 h^{-1}\right)$ : Rate constant for change in cell number,

$\mathrm{k}_{\mathrm{Bmax}, \mathrm{c}}\left(31.3 \times 10^{-3} h^{-1}\right)$ : Rate constant for increase of B max, $\mathrm{c}$ (maximal saturable binding site),

$\mathrm{C}_{\mathrm{total}, \mathrm{c}}, \mathrm{C}_{\text {total, } \mathrm{m}}$ : Total drug concentration in cell and medium.

The mean cell volume is calculated by converting the pixels to micrometers for the ellipsoid MCF7 cell. Experimentally the minimum amount of paclitaxel detectable by Raman microscopy was determined as $100 \mu \mathrm{M}$. Therefore for $3 \mathrm{~h}$ of incubation, using the mean of the pixel of paclitaxel divided by cell pixel (Fig. 5) and multiplying the percentage of cell with paclitaxel, gives the concentration of drug inside the cell. For $3 \mathrm{~h}$ incubation time the Raman measurement gives the concentration of $0.51 \mu \mathrm{M}$, for $6 \mathrm{~h}$ and $9 \mathrm{~h}$ paclitaxel concentrations were $1.84 \mu \mathrm{M}$ and $3.78 \mu \mathrm{M}$, respectively. The numerical solution for the coupled differential equations results in a drug concentration for $3 \mathrm{~h}$ of $0.953 \mu \mathrm{M}$ and of $1.911 \mu \mathrm{M}$ and $2.876 \mu \mathrm{M}$ for $6 \mathrm{~h}$ and $9 \mathrm{~h}$, respectively. The good agreement between the calculated and observed paclitaxel concentration within the cells shows that Raman microscopy can be used to study intracellular pharmacokinetics of paclitaxel.

The main achievements and conclusion of our work can be summarized as follows. Confocal Raman microscopy measurements combined with cluster analysis and correlation map calculations allowed monitoring the internalization of paclitaxel at clinically used concentrations in live MCF7 cancerous cells. Our high resolution images demonstrate that paclitaxel diffuses all over in the cell cytoplasm. The mean diameter of the paclitaxel area measured after cluster analysis for cell incubated $6 \mathrm{~h}$ with paclitaxel is $1.77 \pm 0.27 \mu \mathrm{m}$. This size is compatible with the size of the in-vitro paclitaxel aster-like structure in which the majority of the material is located in the center. An evaluation calculated from Fig 1 in Foss et al. (2008) gives 70\% of the paclitaxel situated in the central area of $1.3 \mu \mathrm{m}$ of diameter.

In a previous work using the $1002 \mathrm{~cm}^{-1}$ Raman band the studied cells have round shape, in contrast with adhered cell shape of the MCF 7 cells. ${ }^{22}$ This might lead to different interpretation due to different cell physiology and difficulty to identify the different cytoplasmic compartments. We have not observed drug localization around bundles of stabilized microtubules that would have been expected according the classical picture of paclitaxel's pharmaceutical action. ${ }^{25}$ Furthermore the validity of all the classical works based on fluorescent labeling is challenged by the theory of paclitaxel crystal formation. This theory is based on in-vitro observation of asterlike paclitaxel crystal and tubulin binding on crystal allowing confusion with microtubule. ${ }^{7,8}$ Paclitaxel crystals inducing sequestration of free tubulin could induce cytotoxicity in nondividing cells leading to cell death rather than by paclitaxel's direct interference with mitotic spindle. ${ }^{12}$ Furthermore, pixel analysis enabled to trace the dynamics of the drug's diffusion process in cells versus time and also a relative quantification of the uptaken amount of paclitaxel. Our work settles bases towards the reinterpretation of chemotherapeutical drug's action on cancerous cells susceptible to promote elaboration of pharmaceutical methods to increase efficiency of anticancer drugs.

${ }^{1}$ N. Desai, V. Trieu, Z. Yao, L. Louie, S. Ci, A. Yang, C. Tao, T. De, B. Beals, D. Dykes et al., Clin. Cancer Res. 12, 1317 (2006).

${ }^{2}$ R. M. R. Gangemi, M. Tiso, C. Marchetti, A. B. Severi, and M. Fabbi, Cancer Chemother. Pharmacol. 36, 385 (1995).

${ }^{3}$ A. Gershlick, I. De Scheerder, B. Chevalier, A. Stephens-Lloyd, E. Camenzind, C. Vrints, N. Reifart, L. Missault, J.-J. Goy, J. A. Brinker et al., Circulation 109, 487 (2004).

${ }^{4}$ A. K. Singla, A. Garg, and D. Aggarwal, Int. J. Pharm. 235, 179 (2002).

${ }^{5}$ W. B. Derry, L. Wilson, and M. A. Jordan, Biochemistry 34, 2203 (1995).

${ }^{6}$ X. P. Wang, T. S. Chen, L. Sun, J. Y. Cai, M. Q. Wu, and M. Mok, Micron 39, 1216 (2008).

${ }^{7}$ J. S. Castro, P. A. Deymier, B. Trzaskowski, and J. Bucay, Colloids Surf., B 76, 199 (2010).

${ }^{8}$ M. Foss, B. W. L. Wilcox, G. B. Alsop, and D. Zhang, PLoS ONE 3, e1476 (2008).

${ }^{9}$ C. Matthäus, T. Chernenko, J. A. Newmark, C. M. Warner, and M. Diem, Biophys. J. 93, 668 (2007).

${ }^{10}$ K. E. Shafer-Peltier, A. S. Haka, J. T. Motz, M. Fitzmaurice, R. R. Dasari, and M. S. Feld, J. Cell Biochem. 87(Suppl. 39), 125 (2002).

${ }^{11}$ C. Krafft, T. Knetschke, A. Siegner, R. H. W. Funk, and R. Salzer, Vib. Spectrosc. 32, 75 (2003).

${ }^{12}$ T. Chernenko, C. Matthaüs, L. Milane, L. Quintero, M. Amiji, and M. Diem, ACS Nano 3, 3552 (2009).

${ }^{13}$ M. M. Mariani, P. J. Day, and V. Deckert, Integr. Biol. 2, 94 (2010).

${ }^{14}$ A. H. Zhou, G. D. McEwen, and Y. Z. Wu, in Microscopy: Science, Technology, Applications and Education A, edited by A. Méndez-Vilas and J. Díaz (FORMATEX, 2010), Vol. 1, p. 515, available at: http:// www.formatex.org.

${ }^{15}$ C. Matthäus, S. Bodyston-White, M. Miljkovic, M. Romeo, and M. Diem, Appl. Spectrosc. 60, 1 (2006).

${ }^{16}$ C. Krafft, B. Dietzek, and J. Popp, Analyst 134, 1046 (2009).

${ }^{17}$ A. Downes and A. Elfick, Sensors 10, 1871 (2010).

${ }^{18}$ K. Hartmann, M. Becker-Putsche, T. Bocklitz, K. Pachmann, A. Niendorf, P. Rösch, and J. Popp, Anal. Bioanal. Chem. 403, 745 (2012).

${ }^{19}$ L. Derely, P. -Y. C. Dutilleul, S. de Welle, V. Szabo, C. Gergely, and F. J. G. Cuisinier, in Nanoscale Imaging, Sensing, and Actuation for Biomedical Applications VIII, edited by A. N. Cartwright and D. V. Nicolau (SPIE, San Francisco, USA, 2011), p. 79080H.

${ }^{20}$ J. Dorney, F. Bonnier, A. Garcia, A. Casey, G. Chambers, and H. Byrne, Analyst 137, 1111 (2012).

${ }^{21}$ M. Miljković, T. Chernenko, M. J. Romeo, B. Bird, C. Matthäus, and M. Diem, Analyst 135, 2002 (2010).

${ }^{22}$ J. Ling, S. D. Weitman, M. A. Miller, R. V. Moore, and A. C. Bovik, Appl. Opt. 41, 6006 (2002).

${ }^{23}$ A. S. Levenson and V. C. Jordan, Cancer Res. 57, 3071 (1997).

${ }^{24}$ H. J. Kuh, S. H. Jang, M. G. Wientjes, and J. L. Au, J. Pharmacol. Exp. Ther. 293, 761 (2000).

${ }^{25}$ P. B. Schiff and S. B. Horwitz, P. Natl. Acad. Sci. USA 77, 1561 (1980). 